Article

\title{
Effects of Surface Modification by Means of Low-Temperature Plasma Nitriding on Wetting and Corrosion Behavior of Austenitic Stainless Steel
}

\author{
Francesca Borgioli *(D), Emanuele Galvanetto and Tiberio Bacci \\ Department of Industrial Engineering, University of Florence, via S. Marta 3, 50139 Florence, Italy; \\ emanuele.galvanetto@unifi.it (E.G.); tiberio.bacci@unifi.it (T.B.) \\ * Correspondence: francesca.borgioli@unifi.it; Tel.: +39-055-275-8734
}

Received: 4 December 2019; Accepted: 21 January 2020; Published: 23 January 2020

check for updates

\begin{abstract}
Low-temperature nitriding of austenitic stainless steels produces modified surface layers, consisting mainly of the $S$ phase, which improve surface hardness and corrosion resistance. Because of the localized plastic deformations, owing to modified layer formation, and ion bombardment occurring during the process itself, this treatment produces also modifications of surface morphology and roughness, which can affect wettability and corrosion behavior. In this study the effects of plasma nitriding, performed using different treatment conditions, on the surface morphology and roughness, and thus on wettability and corrosion resistance, of AISI 202 specimens with different initial finishings (2D and polished finishing) were investigated. Different probe liquids, having both high (bi-distilled water and solution of $3.5 \% \mathrm{NaCl}$ ) and low (ethanol and rapeseed oil) surface tension, were employed for assessing the wetting behavior with the sessile drop method. The contact angle values for water increased markedly when nitriding was performed on polished samples, while this increase was smaller for 2D samples, and on selected specimens a hydrophobic behavior was observed. Very low contact angle values were registered using low surface tension liquids, suggesting an oleophilic behavior. Corrosion resistance in a $5 \% \mathrm{NaCl}$ solution was assessed, and it depended on the characteristics of the nitrided specimens.
\end{abstract}

Keywords: low-temperature nitriding; glow-discharge process; austenitic stainless steels; AISI 202; $S$ phase; wettability; Cassie-Baxter model; Wenzel model; corrosion

\section{Introduction}

Modification of surface topography is one of the main aims of surface engineering. By producing aperiodic or periodic patterns at the micro and/or nano scale, surface roughness changes, and thus may influence wetting behavior of liquids [1-11], lubrication [12-14], friction and wear [15,16], cell adhesion and biocompatibility [17-19].

Surface modification of austenitic stainless steels has been produced by different techniques. Pickling of the surface allows to obtain a fairly high roughness, which promotes lubricant retention [20]. Change from a hydrophilic behavior, typical of a stainless steel surface with a smooth finishing, to a hydrophobic behavior, resulting from a rough surface at the micro/nano scale, has been obtained by chemical treatments [21-23], electrochemical treatments [24,25], femtosecond laser treatments [26,27], and low-energy laser shock peening [28]. The increase of surface roughness has drawbacks: in chloride-ion containing solutions the corrosion resistance tends to decrease as the surface roughness increases [29,30], so that for applications which require very high corrosion resistance, as for stents and implants, a smooth surface, obtained with electrochemical polishing, is preferred [31,32]. 
Low-temperature nitriding of austenitic stainless steels has been recognized to be a useful tool for increasing surface hardness, wear, and corrosion resistance [33,34]. Unlike traditional nitriding treatments, which are usually performed in the range $495-565^{\circ} \mathrm{C}$ and cause the formation of large amounts of chromium nitrides, so that corrosion performances are negatively affected [20,34], low-temperature nitriding is carried out at temperatures lower than $450{ }^{\circ} \mathrm{C}$. At these temperatures, chromium diffusion is very slow, so that the precipitation of chromium nitrides is hindered and a metastable phase is able to form. This phase, usually named the $S$ phase [33-35] or expanded austenite [33,36], solubilizes the nitrogen amount up to about 38 at. \% [37], well beyond the solubility limit. As a consequence, the face-centered cubic (f.c.c.) lattice structure of austenite expands and distorts, with the occurrence of stacking faults and very high compressive stresses [34,36,38]. Hardness values up to about $1500 \mathrm{HV}$ were reported [34], and an improved corrosion resistance in chloride-ion containing solutions, resulting from the beneficial effect of solubilized nitrogen, was registered $[34,39,40]$. The attractive properties of this phase stimulated hundreds of studies regarding the characteristics of the modified layers of low-temperature nitrided austenitic stainless steels and their effects on surface hardness, tribological and fatigue properties, and corrosion resistance [34]. However, the formation of the $S$ phase has additional effects, besides the beneficial increase of surface hardness and corrosion resistance. In fact, because of the local plastic deformations occurring during the formation of the modified layers, also changes of surface topography and roughness were observed [39]. These changes are able to influence the wetting behavior of liquids, but in the international literature this this topic, which should be particularly interesting for extending the possible uses of components subjected to this treatment type, has been neglected, and the studies about the wetting behavior of low-temperature nitrided austenitic stainless steels are few, regarding mainly water wettability [41-48]. The obtained results were not univocal, and the contact angle of water drops on nitrided specimens was reported to decrease $[42-44,46,47]$ or increase $[41,45,47,48]$, in comparison with that for untreated samples. The changes of wetting behavior were investigated mainly for biocompatibility applications on samples having a smooth surface finishing before the treatments [42-44,46,47]. The studies on the effects of nitriding parameters on surface modification and thus on changes of wettability are few $[41,42,44,48]$, and for the most part $[41,42,44]$ they also do not report the influence of the treatments on the corrosion resistance, which remains of paramount importance for these sample types. A lack of information exists also on the influence of the initial surface finishing of the specimens and on the wetting behavior of the modified surfaces by different liquids.

The present study had the aim to investigate how different nitriding conditions were able to modify the surface morphology of samples with different initial surface finishing, and the consequent effects on the wetting by different liquids and on the corrosion resistance, which can be affected by the changes in surface roughness.

It has to be pointed out that, in general, the surface topography and roughness of nitrided austenitic stainless steels depend on three factors: the initial surface finishing of the specimens, the plastic deformations due to the formation of the modified layers, which depend on treatment parameters, and the eventual plasma etching and sputtering, which occur due to ion bombardment in plasma-based processes and also depend on treatment parameters. In order to study the effects of these factors on both the wetting behavior by different liquids and the corrosion resistance of the nitrided specimens, in the present research samples of AISI 202 austenitic stainless steel with two different surface finishings, a rougher 2D state and a smoother polished state, were treated with different nitriding treatments using the glow-discharge process. The low nickel CrMn grade AISI 202 stainless steel was chosen since this alloy, which usually has a lower corrosion resistance in comparison with NiCr AISI 300 series steels, has shown an improvement of corrosion resistance in chloride-ion containing solutions when subjected to low-temperature nitriding [40,49]. Treatment conditions employed in the present study were chosen on the basis of our previous research $[41,49,50]$. A set of samples was subjected to a low-pressure process, similar to cathodic sputtering, so that surface activation, heating, and nitrogen incorporation could occur in a single step with a duration of about $8 \mathrm{~min}$ [48], in order to limit both plastic deformations 
due to the formation of the S-phase layer and the phenomena related to use a plasma process. Nitriding treatments were performed using two different pressures, a high one (1000 Pa), in order to have a less energetic ion bombardment, and a low one (130 Pa), in order to have also an enhanced ion bombardment. Surface morphology, roughness, and phase composition of the untreated and treated samples were evaluated. Wetting behavior was tested by means of the sessile drop method using probe liquids having different surface tensions, bi-distilled water, a solution of $3.5 \% \mathrm{NaCl}$, ethanol, and rapeseed oil. Corrosion behavior of untreated and treated samples in $5 \% \mathrm{NaCl}$ solution was assessed using electrochemical impedance spectroscopy analysis and potentiodynamic tests.

\section{Materials and Methods}

The used AISI 202 austenitic stainless steel had the following chemical composition (in wt.\%): $0.065 \mathrm{C}, 17.0 \mathrm{Cr}, 4.1 \mathrm{Ni}, 7.7 \mathrm{Mn}, 0.40 \mathrm{Si}, 0.15 \mathrm{~N}$. According to X-ray diffraction analysis, austenite and a small amount of ferrite, $\alpha$-Fe (b.c.c.), were present in the steel.

Prismatic samples $(40 \mathrm{~mm} \times 17 \mathrm{~mm} \times 0.7 \mathrm{~mm})$ of AISI 202 were cut from cold-rolled, annealed, and pickled plates. The surface finishing was classified as 2D (EN 10088-2:2005 norm [51]). A set of samples, hereafter named 2D, was not ground and polished further. Another set of samples, hereafter named polished, was ground and polished up to a $6 \mu \mathrm{m}$ diamond suspension.

Treatments were performed with laboratory plasma equipment according to the procedures that were described in previous papers [48,49]. For all the treatment types, the used gas mixture was $80 \mathrm{vol}$. $\% \mathrm{~N}_{2}+20$ vol. $\% \mathrm{H}_{2}$, and the following three different treatment conditions were chosen. Low-pressure treatment, similar to cathodic sputtering, named Type A, was carried out at $130 \mathrm{~Pa}$ fixing the discharge current density and increasing it with two constant steps, while the voltage drop and the treatment temperature increased freely, as previously reported [48]. At the beginning, the current density was fixed at $2.2 \pm 0.1 \mathrm{~mA} \cdot \mathrm{cm}^{-2}$; when the measured temperature was $140{ }^{\circ} \mathrm{C}$, current density was increased and fixed at $2.6 \pm 0.1 \mathrm{~mA} \cdot \mathrm{cm}^{-2}$. With these conditions the voltage drop between the electrodes was allowed to increase from $245 \pm 5 \mathrm{~V}$ (corresponding to room temperature, $23{ }^{\circ} \mathrm{C}$ ) up to $595 \pm 5 \mathrm{~V}$ (corresponding to a measured bulk temperature of $330^{\circ} \mathrm{C}$ ); then the power supply was turned off, the treatment chamber was evacuated, and the samples were allowed to cool down to room temperature under vacuum. The treatment duration was $8 \mathrm{~min}$. A type of nitriding treatment, named Type B, was performed at first with a pre-treatment with Type A conditions, as described above, then increasing pressure and adjusting discharge current, in order to carry out nitriding at $380{ }^{\circ} \mathrm{C}, 1000 \mathrm{~Pa}$, for $5 \mathrm{~h}$. During nitriding, the current density was $1.8 \pm 0.1 \mathrm{~mA} \mathrm{~cm}^{-2}$ and the voltage drop was $158 \pm 10 \mathrm{~V}$. Another type of nitriding treatment, named Type $C$, was performed at first with a pre-treatment with Type A conditions, as described above, then adjusting the discharge current, in order to carry out nitriding at $380^{\circ} \mathrm{C}, 130 \mathrm{~Pa}$, for $5 \mathrm{~h}$. During nitriding, the current density was $0.8 \pm 0.1 \mathrm{~mA} \mathrm{~cm}^{-2}$ and the voltage drop was $221 \pm 10 \mathrm{~V}$. Type $\mathrm{C}$ treatment was performed only on polished samples, since with these treatment conditions sensible amounts of nitrides could be formed on 2D samples $[41,49,50]$.

The surface morphology and microstructure of untreated and nitrided samples were examined using light and scanning electron (SEM; EVO MA 15, Carl Zeiss Microscopy GmbH, Jena, Germany) microscopy and energy-dispersive X-ray spectroscopy (EDS; INCA 250, Oxford Instruments NanoAnalysis, High Wycombe, UK). Cross-section microstructures were analyzed by means of metallographic techniques (chemical etchant: acetic glyceregia $(3 \mathrm{~mL} \mathrm{HCl}, 2 \mathrm{~mL} \mathrm{HNO}, 2 \mathrm{~mL}$ acetic acid, 1 drop of glycerol)).

Phases were identified by means of $X$-ray diffraction analysis ( $\mathrm{Cu} K \alpha$ radiation) in Bragg-Brentano configuration (D8 Advance, Bruker AXS GmbH, Karlsruhe, Germany).

Surface roughness was evaluated with a stylus profilometer. A $2 \mu \mathrm{m}$ radius stylus with a $1 \mathrm{mN}$ contact force was used; the cut-off length was $0.25 \mathrm{~mm}$. The average surface roughness $R_{\mathrm{a}}$, the mean height of profile elements $R_{\mathrm{c}}$, and the maximum height of profile $R_{\mathrm{Z}}$ were recorded. On each sample ten measurements were performed at different locations. 
Wettability of treated and untreated samples by different test liquids was assessed measuring the apparent static contact angle according to the sessile drop method. Test liquids with different surface tension values, $\gamma_{\mathrm{L}}$, were used: bi-distilled water $\left(\gamma_{\mathrm{L}}=72.8 \mathrm{mN} \mathrm{m}^{-1}\right.$ [52]), a solution of $3.5 \%$ $\mathrm{NaCl}$ in bi-distilled water $\left(\gamma_{\mathrm{L}}=73.4 \mathrm{mN} \mathrm{m}^{-1}\right.$ [53]), ethanol $\left(\gamma_{\mathrm{L}}=22.3 \mathrm{mN} \mathrm{m}^{-1}\right.$ [52]), and rapeseed oil $\left(\gamma_{\mathrm{L}}=33.8 \mathrm{mN} \mathrm{m}^{-1}\right.$ [54]) were used; drops of 0.5 or $3 \mu \mathrm{L}$ were employed. Before the measurement, the samples were sonicated in acetone and they were allowed to freely dry in air. All the measurements were taken under ambient laboratory conditions. For each sample the contact angle was measured at least 10 times across the sample surface, and the average value \pm standard deviation was calculated.

Corrosion behavior was studied in $5 \% \mathrm{NaCl}$ solution in naturally aerated conditions at room temperature using a three-electrode flat cell, equipped with an $\mathrm{Ag} / \mathrm{AgCl}$ reference electrode $(3.5 \mathrm{M}$ $\mathrm{KCl}$ ) and a platinum grid as counterelectrode; the sample surface area exposed to the electrolyte was $1 \mathrm{~cm}^{2}$. All the tests were carried out after an $18 \mathrm{~h}$ delay. At least three electrochemical tests for each sample type were performed for assessing the result.

Electrochemical impedance spectroscopy (EIS) measurements were performed at open circuit potential (OCP), in a frequency range of $10 \mathrm{kHz}-12 \mathrm{mHz}$, with 10 points per decade and an ac amplitude (peak-to-peak) of $5 \mathrm{mV}$.

Potentiodynamic polarization tests were carried out using a potential scan rate of $0.3 \mathrm{mV} \mathrm{s}^{-1}$.

\section{Results}

\subsection{Morphology, Microstructure, and Roughness}

The surface morphology of the untreated samples, as supplied with a 2D finishing and after the polishing procedure, is shown in Figure 1. The 2D samples had a dull appearance. Deep grooves, resulting from the pickling procedure, delineated the grain structure, while inside the grains the surface was rough and many pores were present. The surface of polished samples was fairly smooth, with shallow grooves resulting from grinding and polishing. As reported in Table 1, roughness parameters $R_{a}, R_{c}$ and $R_{z}$ were fairly high for $2 \mathrm{D}$ samples, while they were nearly 30 times smaller for the polished samples.

Table 1. Roughness parameters $R_{\mathrm{a}}, R_{\mathrm{c}}$ and $R_{\mathrm{z}}$ for samples untreated and treated as indicated.

\begin{tabular}{cccc}
\hline Sample Type & $\boldsymbol{R}_{\mathbf{a}}(\mu \mathbf{m})$ & $\boldsymbol{R}_{\mathbf{c}}(\mu \mathrm{m})$ & $\boldsymbol{R}_{\mathbf{z}}(\mu \mathbf{m})$ \\
\hline 2D-untreated & $0.22 \pm 0.02$ & $0.81 \pm 0.10$ & $1.31 \pm 0.17$ \\
2D-Type A treated & $0.23 \pm 0.03$ & $0.89 \pm 0.16$ & $1.49 \pm 0.30$ \\
2D-Type B treated & $0.33 \pm 0.01$ & $1.22 \pm 0.07$ & $1.99 \pm 0.15$ \\
Polished-untreated & $0.007 \pm 0.001$ & $0.029 \pm 0.006$ & $0.045 \pm 0.008$ \\
Polished-Type A treated & $0.011 \pm 0.002$ & $0.06 \pm 0.01$ & $0.09 \pm 0.02$ \\
Polished-Type B treated & $0.020 \pm 0.003$ & $0.13 \pm 0.04$ & $0.20 \pm 0.04$ \\
Polished-Type C treated & $0.073 \pm 0.006$ & $0.39 \pm 0.12$ & $0.57 \pm 0.08$ \\
\hline
\end{tabular}
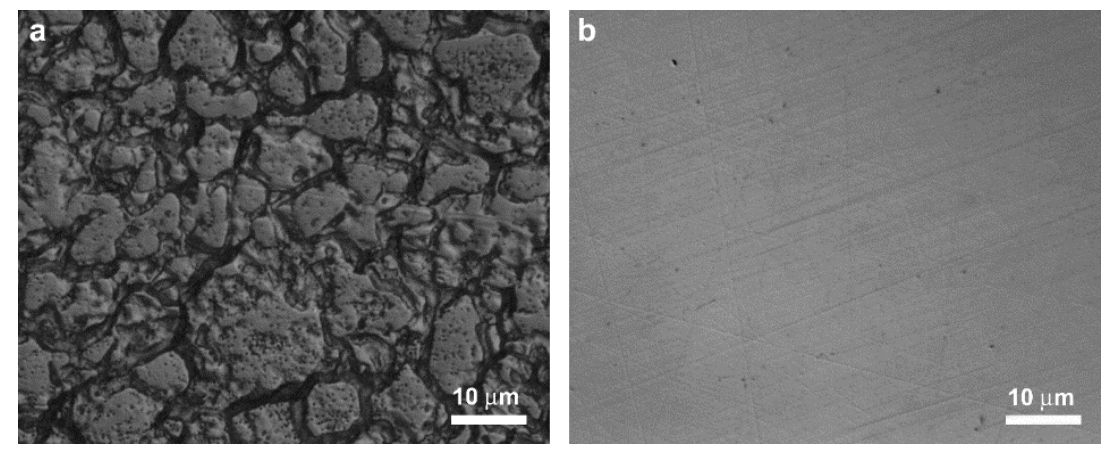

Figure 1. Surface morphology of untreated samples: (a) 2D finishing; (b) polished finishing. 
The surface morphology of 2D samples subjected to Type A and B treatments is depicted in Figure 2. The well delineated grain structure produced by pickling was still observable, and inside the grains the hollows and nanopores were enhanced, as shown in Figure 3, so that an increase of surface roughness was observed.
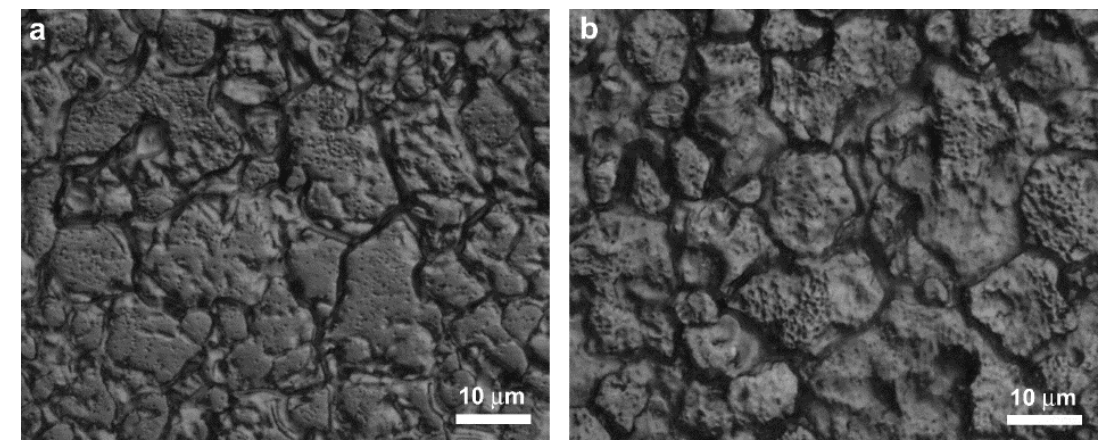

Figure 2. Surface morphology of 2D finished samples treated as indicated: (a) Type A; (b) Type B.

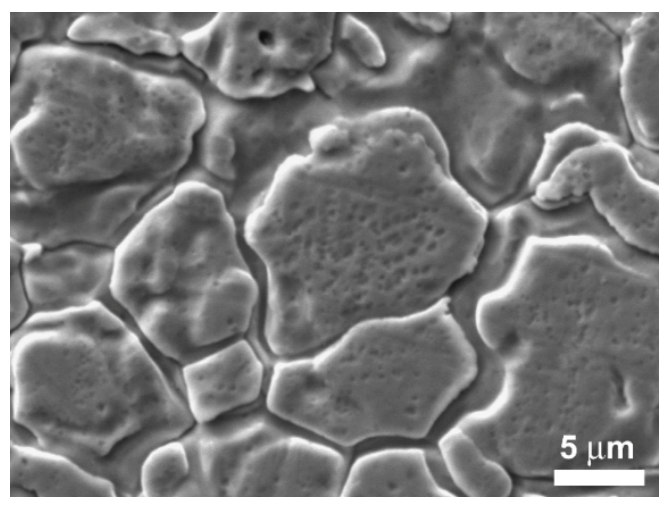

Figure 3. Detail of the surface morphology of a 2D finished sample treated with the Type A conditions.

The surface morphology of polished samples subjected to Type A, B, and C treatments is shown in Figure 4. The sputtering due to ion bombardment caused an etching, which delineated the typical austenitic microstructure with the characteristic twins, and acted selectively on the different grains depending on their orientation. For Type A treated samples, a slight etching was obtained and polishing grooves were still clearly observable (Figure 4a). Shear lines, resulting from plastic deformations produced by modified layer formation, were present. When the nitriding step was also performed, as for Type B and C samples, the etching effect was enhanced, and it depended on treatment conditions. For the Type B treated samples, polishing grooves were still present, but the grain boundaries were well delineated; shear lines were faintly observable inside the grains (Figure $4 b$ ). Sub-micrometric particles, unevenly distributed on the surface, could also be observed (Figure 5a). It may be supposed that these particles formed due to sputtering and subsequent deposition on the surface. EDS analysis showed that the alloy element $(\mathrm{Cr}, \mathrm{Mn}, \mathrm{Ni})$ content of these particles was comparable to that of the matrix. In Type $C$ treated samples, etching was deeper, and the characteristic features, resulting from the plastic deformations caused by the formation of the modified layers, were present. Shear lines were well delineated inside the grains. At grain boundaries, reliefs were present, and some grain boundaries leaned forward on adjacent grains (Figures $4 c$ and $5 b$ ). Even if the etching was not uniform and grains were more or less etched, particles similar to those of Type B treated samples were not observed (Figure 5b). For all sample types, surface roughness significantly increased in comparison with that of untreated specimens, and this enhancement was higher as the etching effect was stronger, that is, for Type $C$ treated samples. 

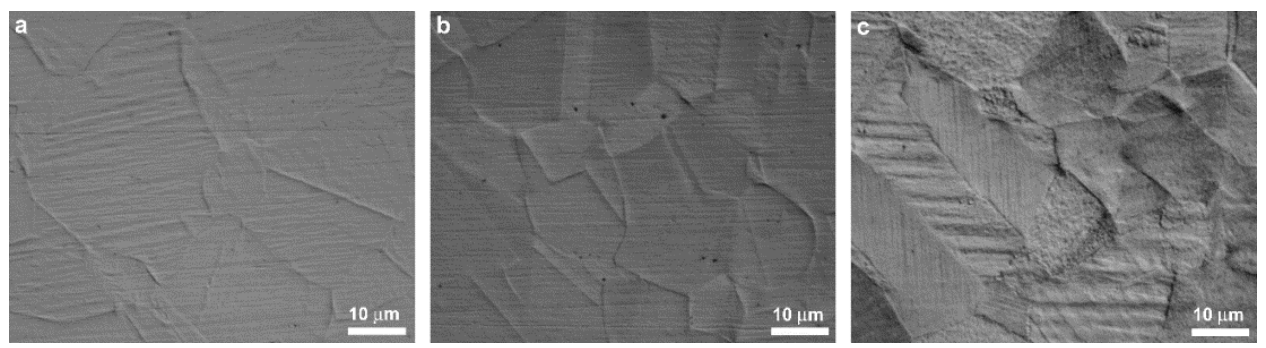

Figure 4. Surface morphology of polished samples treated as indicated: (a) Type A; (b) Type B; (c) Type C.
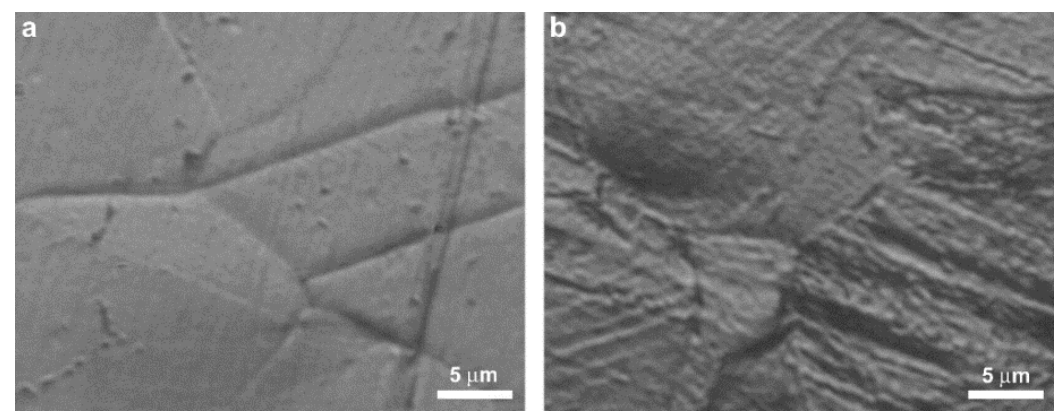

Figure 5. Details of the surface morphology of polished samples treated as indicated: (a) Type B; (b) Type C.

The cross-section microstructure of a polished sample, nitrided with the Type $C$ treatment, is shown as an example in Figure 6. X-ray diffraction patterns of untreated and treated samples are depicted in Figures 7 and 8 for 2D and polished specimens, respectively. For all the sample types, the modified surface layers consisted of an outer layer, in which the $S$ phase was present, and an inner layer, in which a solid solution of interstitial atoms (nitrogen and carbon) in austenite, $\gamma(\mathrm{N}, \mathrm{C})$ (f.c.c.), was detected. EDS analysis showed that the content of alloy elements ( $\mathrm{Cr}, \mathrm{Ni}$, and $\mathrm{Mn}$ ) for these layers and the matrix were comparable. The peaks of the $S$ phase shifted towards lower angles, in comparison with those of austenite, $\gamma$-Fe (f.c.c.). If an f.c.c. lattice is hypothesized also for the $\mathrm{S}$ phase, for all the nitrided samples a decrease of the intensity of the (220) and (311) peaks, if compared to that of the same $\gamma$-Fe peaks, was observed. For samples treated with Type A conditions, the layers were homogeneous and fairly thin, having a thickness, as a whole, of $1.3 \pm 0.1 \mu \mathrm{m}$ for $2 \mathrm{D}$ samples and $1.8 \pm 0.2 \mu \mathrm{m}$ for polished ones. Because of this small thickness, in X-ray patterns the austenite substrate, $\gamma$-Fe, was well detectable. When nitriding was also performed, as for Type B and C samples, groups of shear lines were present in the outer layer, extending from the surface into the layer itself. X-ray diffraction analysis showed that a solid solution of nitrogen in hexagonal close-packed (h.c.p.) martensite, $\varepsilon_{N}{ }^{\prime}$, was also detectable. For polished samples treated with Type B conditions, small peaks ascribable to $\gamma^{\prime}-\mathrm{M}_{4} \mathrm{~N}(\mathrm{M}=\mathrm{Fe}, \mathrm{Cr}, \mathrm{Mn}, \mathrm{Ni})$ nitride were also detected, as depicted in Figure 9, and they are supposed to be related to the sub-micrometric particles observed at the surface. When Type B treatment was carried out, the thickness of the modified layers of 2D samples was $4.9 \pm 0.4 \mu \mathrm{m}$, and it was slightly smaller than that of polished samples, $5.1 \pm 0.3 \mu \mathrm{m}$, as observed for Type A treated specimens. The polished samples treated with Type $C$ conditions had the thickest modified layers, $7.8 \pm 0.5 \mu \mathrm{m}$ as a whole. 


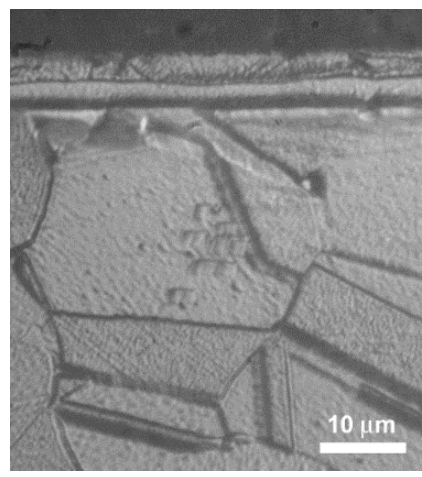

Figure 6. Cross-section microstructure of the modified layers of a polished sample treated with the Type C conditions.

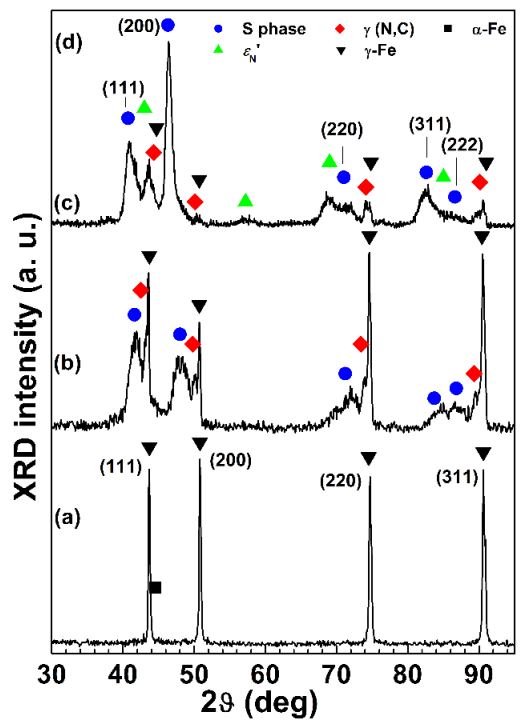

Figure 7. X-ray diffraction patterns of 2D finished samples untreated and treated as indicated: (a) untreated; (b) Type A; (c) Type B; (d) Type C.

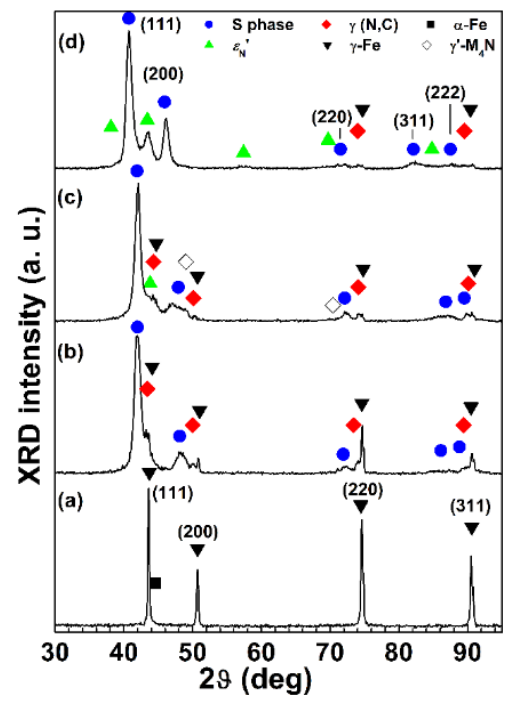

Figure 8. X-ray diffraction patterns of polished samples untreated and treated as indicated: (a) untreated; (b) Type A; (c) Type B; (d) Type C. 


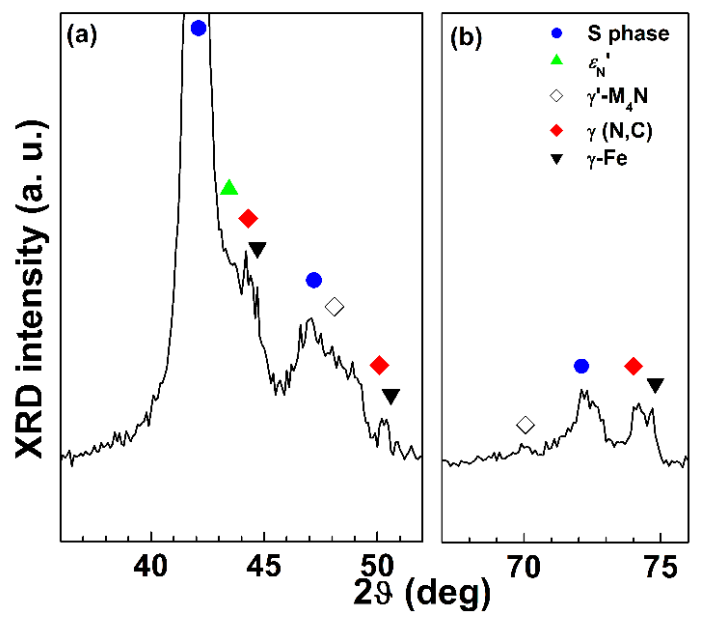

Figure 9. X-ray diffraction pattern (details) of a polished sample treated with Type B conditions.

\subsection{Wettability}

The apparent contact angle (CA) values for untreated and treated samples, measured for 0.5 and $3 \mu \mathrm{L}$ drop sizes of bi-distilled water or a solution with $3.5 \% \mathrm{NaCl}$, are reported in Table 2 , while for samples tested with $0.5 \mu \mathrm{L}$ drop size of ethanol or rapeseed oil they are reported in Table 3 . As an example, the images of $0.5 \mu \mathrm{L}$ drops of bi-distilled water and ethanol on different sample types are depicted in Figures 10 and 11 for 2D samples and polished ones, respectively.

Table 2. Apparent contact angle values of $0.5 \mu \mathrm{L}\left(\mathrm{CA}_{0.5}\right)$ and $3 \mu \mathrm{L}\left(\mathrm{CA}_{3}\right)$ drops of bi-distilled water and a solution with $3.5 \% \mathrm{NaCl}$ for samples untreated and treated as indicated.

\begin{tabular}{ccccc}
\hline \multirow{2}{*}{ Sample Type } & \multicolumn{2}{c}{$\mathbf{B i - D i s t i l l e d ~ W a t e r}$} & \multicolumn{2}{c}{$\mathbf{3 . 5 \%} \mathbf{N a C l}$ Solution } \\
\cline { 2 - 5 } & $\left.\mathbf{C A}_{\mathbf{0 . 5}} \mathbf{(}^{\circ}\right)$ & $\mathbf{C A}_{\mathbf{3}}\left({ }^{\circ}\right)$ & $\left.\mathbf{C A}_{\mathbf{0 . 5}} \mathbf{(}^{\circ}\right)$ & $\left.\mathbf{C A}_{\mathbf{3}} \mathbf{(}^{\circ}\right)$ \\
\hline 2D-untreated & $103 \pm 2$ & $96 \pm 4$ & $103 \pm 2$ & $94 \pm 3$ \\
2D-Type A treated & $110 \pm 3$ & $106 \pm 4$ & $108 \pm 2$ & $102 \pm 4$ \\
2D-Type B treated & $101 \pm 4$ & $93 \pm 4$ & $100 \pm 3$ & $95 \pm 3$ \\
Polished-untreated & $72 \pm 2$ & $65 \pm 3$ & $67 \pm 2$ & $65 \pm 3$ \\
Polished-Type A treated & $97 \pm 3$ & $87 \pm 3$ & $93 \pm 1$ & $88 \pm 4$ \\
Polished-Type B treated & $84 \pm 2$ & $77 \pm 2$ & $81 \pm 2$ & $78 \pm 4$ \\
Polished-Type C treated & $88 \pm 4$ & $81 \pm 1$ & $88 \pm 1$ & $79 \pm 3$ \\
\hline
\end{tabular}

Table 3. Apparent contact angle values of $0.5 \mu \mathrm{L}$ drops of ethanol and rapeseed oil for samples untreated and treated as indicated.

\begin{tabular}{ccc}
\hline Sample Type & $\begin{array}{c}\text { Ethanol } \\
\mathbf{C A}_{\mathbf{0 . 5}}\left(^{\circ}\right)\end{array}$ & $\begin{array}{c}\text { Rapeseed Oil } \\
\mathbf{C A}_{\mathbf{0 . 5}}\left(^{\circ}\right)\end{array}$ \\
\hline 2D-untreated & $13 \pm 2$ & $37 \pm 2$ \\
2D-type A treated & $16 \pm 4$ & $34 \pm 6$ \\
Polished-untreated & $10 \pm 2$ & $29 \pm 1$ \\
Polished-type A treated & $11 \pm 1$ & $30 \pm 1$ \\
\hline
\end{tabular}

For 2D specimens all the sample types were hydrophobic. When Type A treatment was performed, a significant increase of CA was observed, while for Type B treated samples, CA was comparable with that registered for untreated specimens. With $3 \mu \mathrm{L}$ drops, CA values were smaller than those obtained with $0.5 \mu \mathrm{L}$ drops, and this effect was more pronounced for untreated and Type B treated samples. 
a

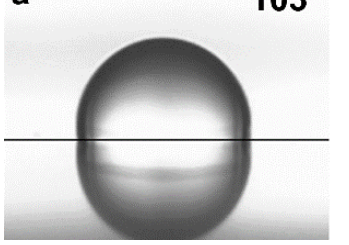

b

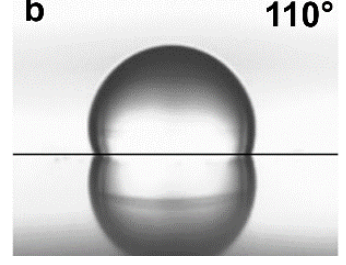

$110^{\circ}$

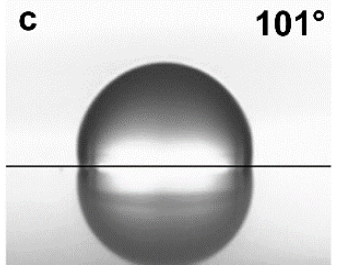

$16^{\circ}$

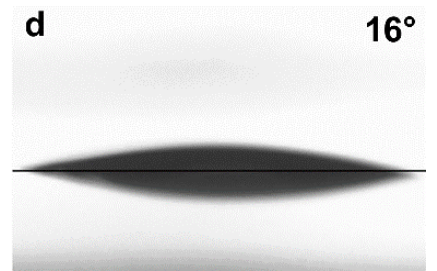

Figure 10. Images of $0.5 \mu \mathrm{L}$ drops deposited on the surface of $2 \mathrm{D}$ finished samples: (a) untreated, bi-distilled water; (b) Type A, bi-distilled water; (c) Type B, bi-distilled water; (d) Type A, ethanol. The black line has been drawn to separate the drop from its reflection.

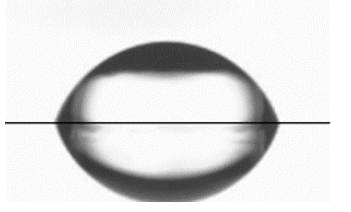

$72^{\circ} \quad$ b

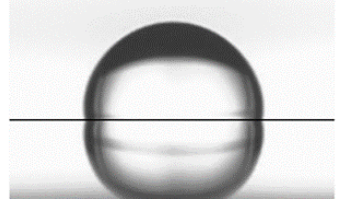

$97^{\circ} \mathrm{C}$

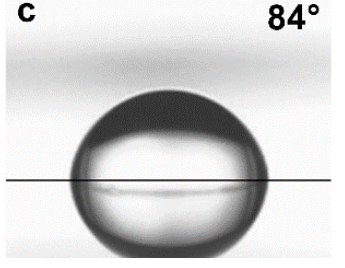

$84^{\circ}$ d $11^{\circ}$

Figure 11. Images of $0.5 \mu \mathrm{L}$ drops deposited on the surface of polished samples: (a) untreated, bi-distilled water; (b) Type A, bi-distilled water; (c) Type B, bi-distilled water; (d) Type A, ethanol. The black line has been drawn to separate the drop from its reflection.

The untreated polished samples showed a hydrophilic surface, even with fairly large CA. Type A treatment caused a significant increase of CA, so that with $0.5 \mu \mathrm{L}$ drops the samples were hydrophobic. When the nitriding step was also performed (Type B and C conditions), an increase of CA was observed, but the samples remained hydrophilic, with Type $C$ treated specimens having the higher $C A$ values. As previously observed, CA values obtained with $0.5 \mu \mathrm{L}$ drops were higher than those measured using $3 \mu \mathrm{L}$ drops.

When the aqueous solution with $3.5 \% \mathrm{NaCl}$ was used, results comparable to those obtained with bi-distilled water were registered.

Wettability of untreated and Type A treated samples was tested also with $0.5 \mu \mathrm{L}$ drops of ethanol or rapeseed oil. As reported in Table 3, for all the tested sample types CA values were fairly small, suggesting an oleophilic behavior. It has to be pointed out that for 2D specimens subjected to Type A nitriding conditions, standard deviations were fairly high, since measured apparent CA values ranged from $11^{\circ}$ to $22^{\circ}$ for ethanol and from $25^{\circ}$ to $42^{\circ}$ for rapeseed oil.

\subsection{Corrosion Behavior}

Representative EIS spectra of untreated and treated specimens tested at the respective open circuit potentials (OCPs) are depicted in Figure 12 in the form of Bode and Nyquist plots for 2D (a,b) and polished $(\mathrm{c}, \mathrm{d})$ samples, respectively.

The Nyquist plots evidenced that, for both treatment types of 2D samples, larger semicircles formed, suggesting that corrosion resistance of these specimen types was improved, in comparison with the untreated samples.

When polished specimens are considered, different behaviors were observed for different treatment types. Type A and C treatments produced an increase of impedance values in comparison with those of untreated samples, so that the portions of the semicircle depicted in Nyquist plots suggested a larger radius, and thus an improved corrosion resistance. On the other hand, Type B samples had low impedance values, so that a reduced corrosion resistance might be expected. 

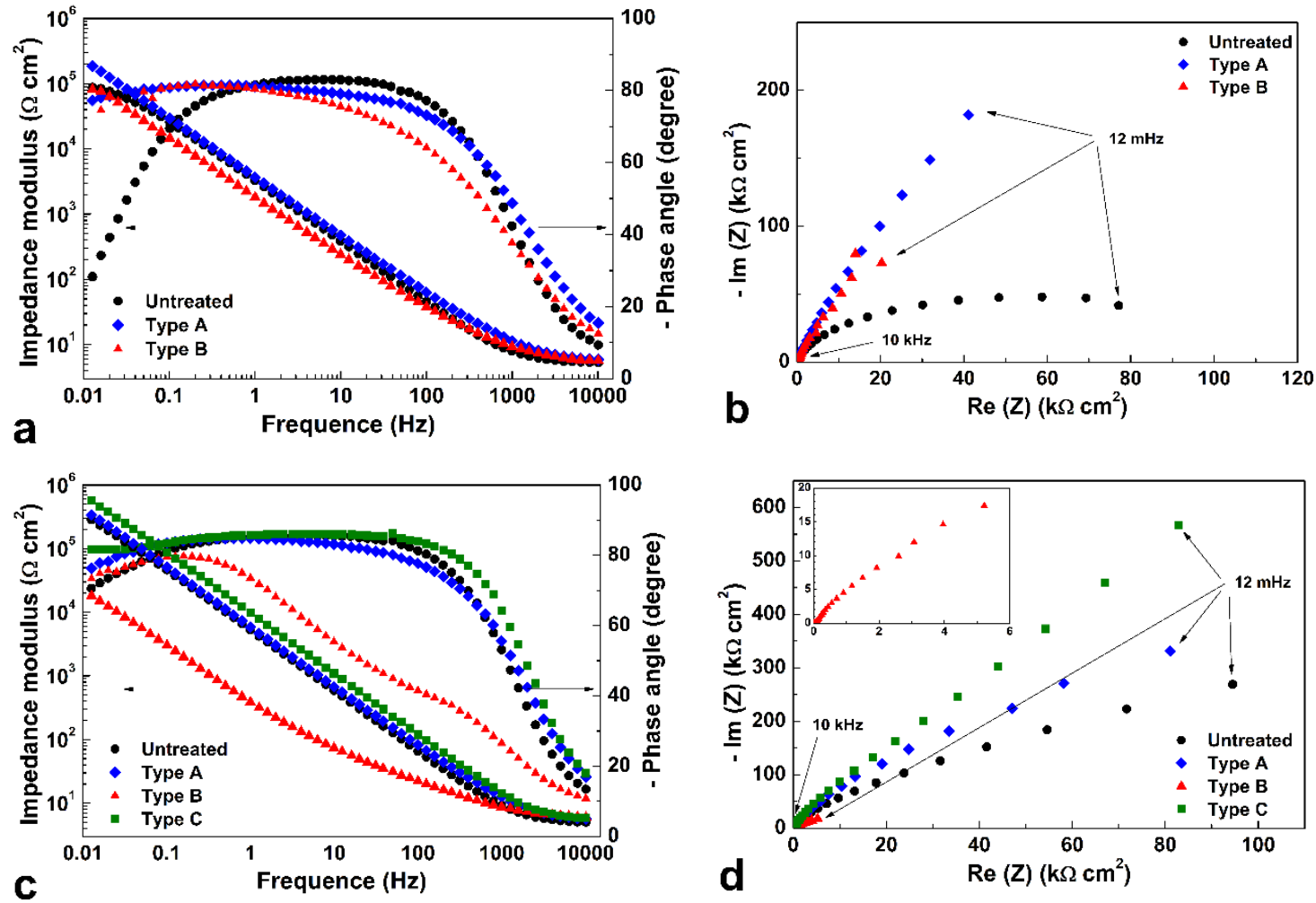

Figure 12. Bode and Nyquist plots for $2 \mathrm{D}(\mathbf{a}, \mathbf{b})$ and polished $(\mathbf{c}, \mathbf{d})$ samples untreated and treated as indicated, recorded at the respective OCP values (solution: $5 \% \mathrm{NaCl}$, aerated). The insert in (d) depicts Nyquist plot of a polished sample nitrided with the Type B conditions.

Typical polarization curves of untreated and treated specimens are shown in Figure 13 for 2D and polished samples.
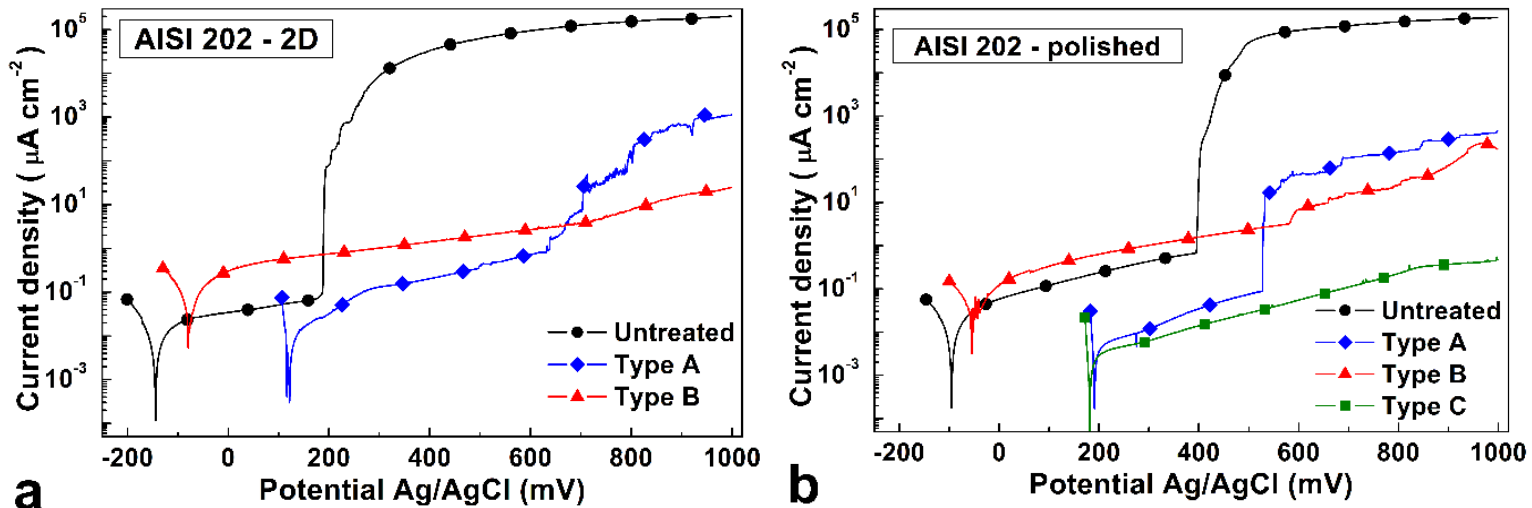

Figure 13. Polarization curves of samples untreated and treated as indicated: (a) 2D finishing; (b) polished finishing (solution: $5 \% \mathrm{NaCl}$, aerated).

All the sample types showed a corrosion behavior that was typical of a passive material subjected to localized corrosion phenomena beyond a threshold of potential values.

For both untreated samples, large anodic current densities were detected beyond pitting potential, and severe pitting and crevices in correspondence with the Teflon gasket occurred. Lower corrosion and pitting potential values were observed for the rougher 2D samples, when compared with those of polished ones. 
Regarding treated 2D samples, for Type A treatment the corrosion potential and the potential at which anodic current density increased, suggesting the occurrence of local corrosion phenomena, were significantly higher in comparison with those of the untreated specimens, and beyond $+200 \mathrm{mV}$ $(\mathrm{Ag} / \mathrm{AgCl})$ the anodic current density values were from 2 to 5 orders of magnitude smaller. After the test, a few shallow pits were observed on the surface of the samples, and a small colored region was present in correspondence with part of the gasket. For Type B samples the increase of the corrosion potential was smaller, and the anodic current values were larger than those observed in the passive branch of untreated and Type A treated specimens. After the test, the surface of the samples showed the presence of some shallow pits and colored regions.

For polished samples, Type A and B treated specimens had a similar behavior to the 2D ones, but for Type B samples, coloring was present on the whole surface. Type $C$ samples showed an improved corrosion resistance, with high corrosion potential and anodic current values that were smaller than $1 \mu \mathrm{A} \mathrm{cm}^{-2}$ for all the tested potential values. After the test the surface was only slightly discolored.

\section{Discussion}

Low-temperature nitriding treatments produced, on austenitic stainless steels, modifications which involved both the surface morphology and the subsurface microstructure of samples, as reported by many authors for both plasma $[34,39,41,55,56]$ and gas $[57,58]$ nitriding. The modifications of surface morphology were well observable on polished specimens. As nitrogen was retained in solid solution of austenite beyond the solubility limit and the $S$ phase formed, the high expansion of the f.c.c. lattice caused local plastic deformations, which could be observed as shear lines at the surface and in the cross-section of the modified layers. Because of these plastic deformations, swelling of the grains was produced, as reported also by Stinville et al. [59]. Moreover, the decrease of the intensity for the diffraction peaks corresponding to (220) and (311) planes, observed for the $S$ phase hypothesizing an f.c.c. crystal lattice like that of the austenite parent phase, suggests that also a rotation of the grains occurred. This phenomenon was observed also by Templier et al. [60] and Stinville et al. [56], who reported that, when nitrided layer formed, the grains at the surface tended to rotate and an evolution towards $<001>$ or $<111>$ orientation occurred, depending on the initial orientation of the grains. As a consequence, in X-ray diffraction patterns the intensity of the peaks of the $S$ phase were affected, so that a marked decrease of the (220) peak was observed [60]. Localized plastic deformations caused also the formation of h.c.p. martensite, $\varepsilon_{N}{ }^{\prime}$, which is considered analogous to strain-induced h.c.p. martensite, $\varepsilon^{\prime}$, but with larger lattice parameters owing to nitrogen solubilization [61]. It is hypothesized that this phase was able to form because of a faulting mechanism [49,61], promoted by the fairly low stacking fault energy of austenitic stainless steels, which was reduced further on by nitrogen solubilization [62,63]. A further surface modification of the nitrided specimens was due to the use of a plasma-based treatment, as the one employed in the present research, which caused a surface etching due to ion bombardment. As observed also by other authors [64], grains with different orientations were more or less etched. Moreover, as previously reported [41,65], etching depth depended on treatment conditions, and it tended to be higher as the pressure was lower, as for Type $C$ treatment, causing a significant increase of surface roughness. In fact, reducing the treatment pressure caused an enhancement of ion and fast neutral energy, owing to the increase of the mean free path and discharge voltage drop, so that the sputtering rate was higher [66], etching due to ion bombardment was deeper, and nitriding was more efficient $[41,65]$. With a pressure of $130 \mathrm{~Pa}$ (Type C), the sputtered material was not redeposited on the surface of the samples. Otherwise, when a higher pressure was employed, as in Type B treatment (1000 Pa), ion bombardment was less energetic and plasma etching was lower, but the presence of sub-micrometric particles on the surface suggests that the sputtered material was able to redeposit on the specimens, probably in the form of $\gamma^{\prime}-\mathrm{M}_{4} \mathrm{~N}$ nitrides, according to X-ray diffraction analysis. Sputtered particles were observed on AISI 316L samples ion-nitrided at $400{ }^{\circ} \mathrm{C}$ [67], and deposits, produced on AISI 304 austenitic stainless steel as a consequence of the sputtering occurring during plasma nitrocarburizing treatments and consisting 
of $\gamma^{\prime}-\mathrm{Fe}_{4} \mathrm{~N}$, were reported by Rolinski [68]. When the treatments were performed with the Type A conditions, the short duration allowed to produce only a slight plasma etching and small local plastic deformations, so that the polishing grooves were still well observable.

The surface features present on polished samples were not clearly observed on nitrided 2D specimens. Even if plastic deformations occurred owing to the formation of the $\mathrm{S}$ phase, as also reported in previous papers [49,63], and some grains tended to rotate, as evidenced by X-ray diffraction analysis, the surface morphology was similar to that of the untreated alloy and shear lines or clear swelling effect were not observable. It may be hypothesized that the rough finishing allowed to partly accommodate the plastic deformations. Moreover, the peaks of the rough surface might enhance the sputtering effect and hinder the redeposition of nitride particles also with a fairly high treatment pressure, as that used for Type B treatment. The small increase of corrosion potential and fairly large anodic current values of these sample types may suggest that some nitride particles were still able to deposit on the surface, even if their presence was not registered by X-ray diffraction analysis or microscopy observations.

The different effect of initial surface finishing influenced also the roughness values and the modified layer thickness of the nitrided samples. In fact, even if the surface roughness of the 2D samples was fairly high, the increase in $R_{\mathrm{a}}, R_{\mathrm{c}}$ and $R_{\mathrm{z}}$ values of the nitrided specimens, compared to those of the untreated ones, was lower than that observed for polished samples. For example, referring to $R_{\mathrm{a}}$ parameter, when Type B conditions were used, $R_{\mathrm{a}}$ values for polished samples increased about 3 times, while for $2 \mathrm{D}$ specimens the increase was only about 1.4 times. The effect on the modified layer thickness was smaller, with the 2D samples having slightly thinner nitrided layers, in comparison with polished ones treated with the same conditions. Similar observations were made also by Singh et al. [69], who reported higher roughness increase and thicker nitrided layers for plasma-nitrided AISI 304 specimens when their initial surface finishing was mirror polished, in comparison with a grinding procedure.

The surface morphology and roughness changes due to low-temperature nitriding treatments influenced wettability. A drop of liquid on a real rough surface can adopt one of the following configurations: a Wenzel state [70] or a Cassie-Baxter state [71]. For the Wenzel state, the drop has complete contact with the surface, permeating the protrusions. The apparent $\mathrm{CA}$, formed by the liquid drop on the rough surface, $\vartheta_{\text {rough }}$, is related to the intrinsic CA, formed on an ideal flat surface, $\vartheta_{\text {flat }}$, according to the following relation:

$$
\cos \vartheta_{\text {rough }}=r \cos \vartheta_{\text {flat }}
$$

where the roughness factor, $r$, is the ratio of the area of the real rough surface to the geometric area projected on the horizontal plane. Since $r$ is larger than 1, roughness amplifies both the wetting and nonwetting behavior of the surface, so that hydrophilic surfaces $\left(\vartheta_{\text {flat }}<90^{\circ}\right)$ become more hydrophilic $\left(\vartheta_{\text {rough }}<\vartheta_{\text {flat }}\right)$ and hydrophobic surfaces $\left(\vartheta_{\text {flat }}>90^{\circ}\right)$ become more hydrophobic $\left(\vartheta_{\text {rough }}>\vartheta_{\text {flat }}\right)$. For the Cassie-Baxter state, the drop lies on a composite surface consisting of the top of the asperities of the solid and air pockets trapped underneath the liquid. This situation can be described by the following relation:

$$
\cos \vartheta_{\text {rough }}=\phi_{\mathrm{s}}\left(1+\cos \vartheta_{\text {flat }}\right)-1
$$

where $\phi_{\mathrm{s}}$ is the area fraction of the solid surface in contact with the liquid, and it is smaller than 1 . Thus, the apparent CA is larger than that formed on an ideal flat surface. For hydrophilic surfaces the Cassie-Baxter state is metastable, and it is obtained when suitable surface features as microtextures or overhanging structures prevent water from entering into the cavities $[1,2]$.

In the present research, when bi-distilled water was used as probe liquid, the nitriding treatments produced an increase of the apparent CA values in comparison with those of untreated samples; thus, it may be hypothesized that drops were fakir drops in a Cassie-Baxter state, as observed also in our previous research $[41,48]$. The comparison between the apparent $C A$ values and roughness values showed that the effect of surface morphology is complex. For both polished and 2D samples, the highest CA values, corresponding to a hydrophobic behavior, were measured for Type A treatment, which 
did not produce the roughest surfaces. The effects of this treatment were well observable on polished samples as a slight surface etching and small local plastic deformations, but a similar effect might occur on $2 \mathrm{D}$ samples. It may be hypothesized that this slight change of surface morphology and roughness is able to produce tiny air pockets, which effectively support the drop. For nitrided polished samples, the treatments increased surface roughness, but they produced different morphologies. For Type B treated samples, the surface was modified by a combination of surface etching, plastic deformations, and small sub-micrometric particles, while for type $C$ nitrided samples a strong etching due to ion bombardment and large plastic deformations occurred. It may be supposed that both these treatment conditions were able only in part to produce air pockets able to bear the drop, with the best results obtained with the roughest surface (i.e., using Type $C$ conditions). The rough surface of the $2 \mathrm{D}$ finishing caused a marked increase of the apparent CA, so that for all the samples a hydrophobic behavior was registered. For Type A treated samples, the largest apparent CA was observed. When Type B treatment was performed, CA values were comparable with those of the untreated specimens, even if an increase of surface roughness was registered. It may be hypothesized that the plastic deformations occurring during nitriding slightly modified the surface and acted to reduce the air pockets. For all the sample types, when the drop size was increased from 0.5 to $3 \mu \mathrm{L}$, smaller apparent $C A$ values were measured, so that a partial impalement of the fakir drops on the surface peaks may be hypothesized, owing to the higher hydrostatic pressure. It has to be pointed out that these results are not in accordance with those obtained by Lin et al. [42] and Buhagiar et al. [43], who observed a decrease of water CA values for the nitrided specimens in comparison with those for the untreated alloy. It may be supposed that for their test conditions, for which drop size was not specified, the drops were nearly in a Wenzel state.

When a $3.5 \% \mathrm{NaCl}$ solution was used as probe liquid, the measured $\mathrm{CA}$ values were similar to those obtained for bi-distilled water, as expected for liquids having comparable surface tension. For probe liquids having a low surface tension, as ethanol and rapeseed oil, the apparent CA was very small for both untreated and Type A treated samples, suggesting an oleophilic behavior. A similar behavior was observed on hydrophobic and superhydrophobic surfaces, such as that of Nelumbo nucifera, which was completely wet by drops of low surface tension liquids as hexadecane [6], and it was obtained on metallic surfaces using different strategies [8]. It is interesting to note that the apparent CA values of 2D samples treated with Type A conditions, even if they were comparable with those of untreated specimens, had a larger standard deviation, since a large range of values was registered. It may be hypothesized that it depended on local surface morphology, which tended to promote a Wenzel state instead of a Cassie-Baxter state, in which the valleys were in part filled with liquid.

Both surface finishing and nitriding treatments were able to influence corrosion behavior. As expected, the untreated specimens had better corrosion resistance when they had a polished finishing than with a rougher 2D finishing, since with a smoother surface the possible sites for pits are more open, preventing the accumulation of $\mathrm{Cl}^{-}$and $\mathrm{H}^{+}$, so that metastable pits are less capable of propagating, and a higher potential is required to cause a stable pitting [29]. The formation of nitrogen-enriched modified surface layers, consisting mainly of the $S$ phase, had a beneficial effect, as previously reported [34,39,40,72]. Different theories were proposed to explain the protection mechanism of nitrogen in austenitic stainless steels $[33,40]$, and it was supposed that these mechanisms are similar to those occurring for low-temperature nitrided austenitic stainless steels $[34,72,73]$. In particular, nitrogen atoms, solubilized in the $\mathrm{S}$ phase and released in the early stages of corrosion, may react with protons, $\mathrm{H}^{+}$, and form ammonium ions, $\mathrm{NH}_{4}{ }^{+}$, according to the reaction

$$
[\mathrm{N}]+4 \mathrm{H}^{+}+3 \mathrm{e}^{-} \rightarrow \mathrm{NH}_{4}^{+}
$$

so that an increase of $\mathrm{pH}$ occurs. Thus, a local neutralizing effect in acidic pits may happen when the concentration of formed ammonium ions is sufficient, and pits are able to repassivate [72,73]. As long as nitrogen is present in solid solution in the $\mathrm{S}$ phase, it can be released and cause a local alkalinization and hinder stable pit formation, leading to an increase of corrosion potential and pitting potential [72]. 
Type A treatment was able to significantly improve corrosion resistance, in comparison with the untreated samples, even if the modified surface layers were fairly thin. For polished samples treated with Type B conditions, EIS analysis suggested a poor corrosion resistance, which was not observed with the potentiodynamic test. It may be hypothesized that the deposited $\gamma^{\prime}-\mathrm{M}_{4} \mathrm{~N}$ particles produced an inhomogeneous surface, which acted to reduce the impedance values of the specimens, as registered by EIS analysis. During the potentiodynamic tests, these particles were fast oxidized, causing the observed slighter increase of corrosion potential and larger anodic current values, and then the $S$ phase present in the modified surface layers could hinder the corrosion phenomena. For the samples with the 2D finishing treated with the same conditions, the redeposition of sputtered particles was hindered; thus, higher impedance values than those of polished samples were registered. In spite of their high roughness, polished samples treated with the Type $C$ conditions showed the highest corrosion resistance. It may be hypothesized that it was due to the nitrogen-rich layers consisting of the $\mathrm{S}$ phase having an adequate thickness for counteracting corrosion phenomena. It has to be noted that the increase of surface roughness due to the nitriding treatment did not adversely affect the corrosion resistance, but that the occurrence of corrosion phenomena depended on the thickness of the modified layers and the eventual formation of nitride precipitates.

\section{Conclusions}

Low-temperature plasma nitriding, carried out on AISI 202 austenitic stainless steel, produced modified surface layers, consisting mainly of the $S$ phase, and their formation affected surface morphology and roughness of the samples. When the samples had a 2D finishing, the rough surface was only slightly affected by the treatments, and a moderate increase of surface roughness was observed. Otherwise, when the samples were polished before nitriding, both localized plastic deformations, owing to the formation of the modified layers, and ion bombardment due to the plasma treatments markedly changed the surface morphology, and a significant increase of surface roughness was registered. With low-pressure treatments having a short duration (Type A), analogous to cathodic sputtering, a slight etching of the surface was produced, and a low roughness increase was observed. When nitriding was performed at $1000 \mathrm{~Pa}$ (Type B), etching was deeper, plastic deformations were observable, and many sub-micrometric nitride particles, probably formed due to sputtering and redeposition, were present on the surface. As a consequence, an increase of roughness was registered. With nitriding at lower pressure (130 Pa) (Type C), plasma etching was enhanced, and the effects of plastic deformations were well observable at the surface also because nitriding was more efficient with these conditions, and surface roughness increased further on. These changes affected wettability of the samples. For 2D samples, a hydrophobic behavior was observed for both untreated and treated samples. For polished samples, an increase of apparent contact angle values was registered for all treatment types, in comparison with those of untreated specimens, but a hydrophobic behavior was observed only for samples subjected to Type A treatment when $0.5 \mu \mathrm{L}$ drops were used. It may be supposed that, for all the treated samples, drops were in a Cassie-Baxter state. On the contrary, using liquids with lower surface tension, as ethanol and rapeseed oil, an oleophilicity was observed. For all the nitrided samples, an increase of the corrosion resistance in $5 \% \mathrm{NaCl}$ was registered, and the occurrence of corrosion phenomena depended on the thickness of the modified layers and the eventual formation of nitride precipitates, while the increase of surface roughness did not adversely affect the corrosion resistance.

Author Contributions: Conceptualization, F.B., E.G., and T.B.; software, E.G.; formal analysis, F.B. and E.G.; investigation, F.B. and E.G.; writing—original draft preparation, F.B.; writing—review and editing, F.B. and E.G.; supervision, F.B.; project administration, F.B.; funding acquisition, F.B. and T.B. All authors have read and agreed to the published version of the manuscript.

Funding: This research was funded by MIUR (Ministero dell'Istruzione, dell'Università e della Ricerca; years 2014, 2015). 
Acknowledgments: ThyssenKrupp Acciai Speciali Terni (Terni, Italy) is acknowledged for providing the AISI 202 steel.

Conflicts of Interest: The authors declare no conflict of interest.

\section{References}

1. Quéré, D. Wetting and Roughness. Annu. Rev. Mater. Res. 2008, 38, 71-99. [CrossRef]

2. Cao, L.; Hu, H.A.; Gao, D. Design and fabrication of micro-textures for inducing a superhydrophobic behavior on hydrophilic materials. Langmuir 2007, 23, 4310-4314. [CrossRef] [PubMed]

3. Duan, J.-A.; Dong, X.; Yin, K.; Yang, S.; Chu, D. A hierarchical superaerophilic cone: Robust spontaneous and directional transport of gas bubbles. Appl. Phys. Lett. 2018, 113, 203704. [CrossRef]

4. Sheng, Y.J.; Jiang, S.; Tsao, H.K. Effects of geometrical characteristics of surface roughness on droplet wetting. J. Chem. Phys. 2007, 127, 234704. [CrossRef]

5. Whyman, G.; Bormashenko, E. How to make the Cassie wetting state stable? Langmuir 2011, 27, 8171-8176. [CrossRef]

6. Tuteja, A.; Choi, W.; Mckinley, G.H.; Cohen, R.E.; Rubner, M.F. Design Parameters for Superhydrophobicity and Superoleophobicity. MRS Bull. 2008, 33, 752-758. [CrossRef]

7. Kota, A.K.; Mabry, J.M.; Tuteja, A. Superoleophobic surfaces: Design criteria and recent studies. Surf. Innov. 2013, 1, 71-83. [CrossRef]

8. Liu, K.; Jiang, L. Metallic surfaces with special wettability. Nanoscale 2011, 3, 825-838. [CrossRef]

9. Yin, K.; Du, H.; Dong, X.; Wang, C.; Duan, J.-A.; He, J. A simple way to achieve bioinspired hybrid wettability surface with micro/nanopatterns for efficient fog collection. Nanoscale 2017, 9, 14620-14626. [CrossRef]

10. Yang, S.; Yin, K.; Chu, D.; He, J.; Duan, J.-A. Femtosecond laser structuring of Janus foam: Water spontaneous antigravity unidirectional penetration and pumping. Appl. Phys. Lett. 2018, 113, 203701. [CrossRef]

11. Yang, S.; Yin, K.; Wu, J.; Wu, Z.; Chu, D.; He, J.; Duan, J.-A. Ultrafast nano-structuring of superwetting Ti foam with robust antifouling and stability towards efficient oil-in-water emulsion separation. Nanoscale 2019, 11, 17607-17614. [CrossRef] [PubMed]

12. Tzeng, S.T.; Saibel, E. Surface roughness effect on slider bearing lubrication. ASLE Trans. 1967, 10, 334-348. [CrossRef]

13. Boer, D.; Ehl, T.; De Boer, G.N.; Hewson, R.W.; Thompson, H.M.; Gao, L.; Toropov, V.V. Two-scale EHL: Three-dimensional topography in tilted-pad bearings. Tribol. Int. 2014, 79, 111-125. [CrossRef]

14. Sudeep, U.; Tandon, N.; Pandey, R.K. Performance of lubricated rolling/sliding concentrated contacts with surface textures: A review. J. Tribol. 2015, 137, 031501. [CrossRef]

15. Gachot, C.; Rosenkranz, A.; Hsu, S.M.; Costa, H.L. A critical assessment of surface texturing for friction and wear improvement. Wear 2017, 372-373, 21-41. [CrossRef]

16. Grützmacher, P.G.; Profito, F.J.; Rosenkranz, A. Multi-Scale Surface Texturing in Tribology-Current Knowledge and Future Perspectives. Lubricants 2019, 7, 95. [CrossRef]

17. Roach, P.; Eglin, D.; Rohde, K.; Perry, C.C. Modern biomaterials: A review-Bulk properties and implications of surface modifications. J. Mater. Sci. Mater. Med. 2007, 18, 1263-1277. [CrossRef]

18. Von Recum, A.F.; Shannon, C.E.; Cannon, C.E.; Long, K.J.; van Kooten, T.G.; Meyle, J. Surface Roughness, Porosity, and Texture as Modifiers of Cellular Adhesion. Tissue Eng. 1996, 2, 241-253. [CrossRef]

19. Elter, P.; Sickel, F.; Ewald, A. Nanoscaled periodic surface structures of medical stainless steel and their effect on osteoblast cells. Acta Biomater. 2009, 5, 1468-1473. [CrossRef]

20. Davis, J.R. Surface Engineering of Stainless Steels. In ASM Metal Handbook; ASM International: Materials Park, OH, USA, 1994; Volume 5, pp. 741-761. [CrossRef]

21. Kim, J.H.; Mirzaei, A.; Kim, H.W.; Kim, S.S. Facile fabrication of superhydrophobic surfaces from austenitic stainless steel (AISI 304) by chemical etching. Appl. Surf. Sci. 2018, 439, 598-604. [CrossRef]

22. Pantoja, M.; Velasco, F.; Abenojar, J.; Martinez, M.A. Development of superhydrophobic coatings on AISI 304 austenitic stainless steel with different surface pretreatments. Thin Solid Film. 2019, 671, 22-30. [CrossRef]

23. Gao, L.; Yang, S.; Yang, H.; Ma, T. One-Stage Method for Fabricating Superhydrophobic Stainless Steel Surface and Its Anti-Corrosion Performance. Adv. Eng. Mater. 2017, 19, 1-6. [CrossRef]

24. Choi, W.T.; Oh, K.; Singh, P.M.; Breedveld, V.; Hess, D.W. Wettability control of stainless steel surfaces via evolution of intrinsic grain structures. J. Mater. Sci. 2016, 51, 5196-5206. [CrossRef] 
25. Choi, W.T.; Oh, K.; Singh, P.M.; Breedveld, V.; Hess, D.W. Hydrophobicity and improved localized corrosion resistance of grain boundary etched stainless steel in chloride-containing environment. J. Electrochem. Soc. 2017, 164, C61-C65. [CrossRef]

26. Bizi-Bandoki, P.; Benayoun, S.; Valette, S.; Beaugiraud, B.; Audouard, E. Modifications of roughness and wettability properties of metals induced by femtosecond laser treatment. Appl. Surf. Sci. 2011, 257, 5213-5218. [CrossRef]

27. Martínez-Calderon, M.; Rodríguez, A.; Dias-Ponte, A.; Morant-Miñana, M.C.; Gómez-Aranzadi, M.; Olaizola, S.M. Femtosecond laser fabrication of highly hydrophobic stainless steel surface with hierarchical structures fabricated by combining ordered microstructures and LIPSS. Appl. Surf. Sci. 2016, 374, 81-89. [CrossRef]

28. Prabhakaran, S.; Kulkarni, A.; Vasanth, G.; Kalainathan, S.; Shukla, P.; Vasudevan, V.K. Laser shock peening without coating induced residual stress distribution, wettability characteristics and enhanced pitting corrosion resistance of austenitic stainless steel. Appl. Surf. Sci. 2018, 428, 17-30. [CrossRef]

29. Burstein, G.T.; Vines, S.P. Repetitive Nucleation of Corrosion Pits on Stainless Steel and the Effects of Surface Roughness. J. Electrochem. Soc. 2001, 148, 504-516. [CrossRef]

30. Hilbert, L.R.; Bagge-Ravn, D.; Kold, J.; Gram, L. Influence of surface roughness of stainless steel on microbial adhesion and corrosion resistance. Int. Biodeterior. Biodegrad. 2003, 52, 175-185. [CrossRef]

31. Habibzadeh, S.; Li, L.; Shum-Tim, D.; Davis, E.C.; Omanovic, S. Electrochemical polishing as a 316L stainless steel surface treatment method: Towards the improvement of biocompatibility. Corros. Sci. 2014, 87, 89-100. [CrossRef]

32. O'Brien, B.; Carroll, W. The evolution of cardiovascular stent materials and surfaces in response to clinical drivers: A review. Acta Biomater. 2009, 5, 945-958. [CrossRef] [PubMed]

33. Lo, K.H.; Shek, C.H.; Lai, J.K.L. Recent developments in stainless steels. Mater. Sci. Eng. R Reports 2009, 65, 39-104. [CrossRef]

34. Dong, H. S-phase surface engineering of Fe-Cr, $\mathrm{Co}-\mathrm{Cr}$ and Ni-Cr alloys. Int. Mater. Rev. 2010, 55, 65-98. [CrossRef]

35. Fossati, A.; Borgioli, F.; Galvanetto, E.; Bacci, T. Corrosion resistance properties of glow-discharge nitrided AISI 316L austenitic stainless steel in $\mathrm{NaCl}$ solutions. Corros. Sci. 2006, 48, 1513-1527. [CrossRef]

36. Christiansen, T.L.; Somers, M.A.J. Low-temperature gaseous surface hardening of stainless steel: The current status. Zeitschrift fuer Met. Res. Adv. Tech. 2009, 100, 1361-1377. [CrossRef]

37. Christiansen, T.; Somers, M.A.J. Controlled dissolution of colossal quantities of nitrogen in stainless steel. Metall. Mater. Trans. A 2006, 37, 675-682. [CrossRef]

38. Tong, K.; Ye, F.; Che, H.; Lei, M.K.; Miao, S.; Zhang, C. High-density stacking faults in a supersaturated nitrided layer on austenitic stainless steel. J. Appl. Crystallogr. 2016, 49, 1967-1971. [CrossRef]

39. Fossati, A.; Galvanetto, E.; Bacci, T.; Borgioli, F. Improvement of corrosion resistance of austenitic stainless steels by means of glow-discharge nitriding. Corros. Rev. 2011, 29, 209-221. [CrossRef]

40. Borgioli, F.; Galvanetto, E.; Bacci, T. Corrosion behaviour of low temperature nitrided nickel-free, AISI 200 and AISI 300 series austenitic stainless steels in $\mathrm{NaCl}$ solution. Corros. Sci. 2018. [CrossRef]

41. Borgioli, F.; Galvanetto, E.; Bacci, T. Influence of surface morphology and roughness on water wetting properties of low temperature nitrided austenitic stainless steels. Mater. Charact. 2014, 95, 278-284. [CrossRef]

42. Lin, Y.H.; Lan, W.C.; Ou, K.L.; Liu, C.M.; Peng, P.W. Hemocompatibility evaluation of plasma-nitrided austenitic stainless steels at low temperature. Surf. Coat. Technol. 2012, 206, 4785-4790. [CrossRef]

43. Buhagiar, J.; Bell, T.; Sammons, R.; Dong, H. Evaluation of the biocompatibility of S-phase layers on medical grade austenitic stainless steels. J. Mater. Sci. Mater. Med. 2011, 22, 1269-1278. [CrossRef] [PubMed]

44. Galeano-Osorio, D.S.; Vargas, S.; Vélez, J.M.; Mello, A.; Tanaka, M.N.; Castano, C.E. Hemocompatibility of plasma nitrided 316L stainless steel: Effect of Processing Temperature. Appl. Surf. Sci. 2019, 144704. [CrossRef]

45. Aizawa, T.; Morita, H.; Wasa, K. Low-temperature plasma nitriding of mini-/micro-tools and parts by table-top system. Appl. Sci. 2019, 9, 1667. [CrossRef]

46. Braz, J.K.F.S.; Martins, G.M.; Sabino, V.; Vitoriano, J.O.; Barboza, C.A.G.; Soares, A.K.M.C.; Rocha, H.A.O.; Oliveira, M.F.; Alves Júnior, C.; Moura, C.E.B. Plasma nitriding under low temperature improves the endothelial cell biocompatibility of 316L stainless steel. Biotechnol. Lett. 2019, 41, 503-510. [CrossRef] [PubMed] 
47. Martinesi, M.; Stio, M.; Treves, C.; Borgioli, F. Biocompatibility studies of low temperature nitrided and collagen-I coated AISI 316L austenitic stainless steel. J. Mater. Sci. Mater. Med. 2013, 24, 1501-1513. [CrossRef]

48. Borgioli, F.; Galvanetto, E.; Bacci, T. Surface modification of austenitic stainless steel by means of low pressure glow-discharge treatments with nitrogen. Coatings 2019, 9, 604. [CrossRef]

49. Borgioli, F.; Fossati, A.; Matassini, G.; Galvanetto, E.; Bacci, T. Low temperature glow-discharge nitriding of a low nickel austenitic stainless steel. Surf. Coat. Technol. 2010, 204, 3410-3417. [CrossRef]

50. Borgioli, F.; Fossati, A.; Raugei, L.; Galvanetto, E.; Bacci, T. Low temperature glow-discharge nitriding of stainless steels. In Proceedings of the 7th European Stainless Steel Conference: Science and Market, Como, Italy, 21-23 September 2011; Associazione Italiana di Metallurgia: Milan, Italy, 2011.

51. EN 10088-2:2005, Stainless Steels. Part 2: Technical Delivery Conditions for Sheet/Plate and Strip of Corrosion Resisting Steels for General Purposes; European Committee for Standardization (CEN): Brussels, Belgium, 2005.

52. Vazquez, G.; Alvarez, E.; Navaza, J.M. Surface Tension of Alcohol + Water from 20 to $50{ }^{\circ}$ C. J. Chem. Eng. Data 1995, 40, 611-614. [CrossRef]

53. Ozdemir, O.; Karakashev, S.I.; Nguyen, A.V.; Miller, J.D. Adsorption and surface tension analysis of concentrated alkali halide brine solutions. Miner. Eng. 2009, 22, 263-271. [CrossRef]

54. Esteban, B.; Riba, J.R.; Baquero, G.; Puig, R.; Rius, A. Characterization of the surface tension of vegetable oils to be used as fuel in diesel engines. Fuel 2012, 102, 231-238. [CrossRef]

55. Liang, W.; Xiaolei, X.; Jiujun, X.; Yaqin, S. Characteristics of low pressure plasma arc source ion nitrided layer on austenitic stainless steel at low temperature. Thin Solid Film. 2001, 391, 11-16. [CrossRef]

56. Stinville, J.C.; Cormier, J.; Templier, C.; Villechaise, P. Modeling of the lattice rotations induced by plasma nitriding of 316L polycrystalline stainless steel. Acta Mater. 2015, 83, 10-16. [CrossRef]

57. Baranowska, J.; Arnold, B. Corrosion resistance of nitrided layers on austenitic steel. Surf. Coat. Technol. 2006, 200, 6623-6628. [CrossRef]

58. Baranowska, J.; Franklin, S.E.; Kochmańska, A. Wear behaviour of low-temperature gas nitrided austenitic stainless steel in a corrosive liquid environment. Wear 2007, 263, 669-673. [CrossRef]

59. Stinville, J.C.; Templier, C.; Villechaise, P.; Pichon, L. Swelling of 316L austenitic stainless steel induced by plasma nitriding. J. Mater. Sci. 2011, 46, 5503-5511. [CrossRef]

60. Templier, C.; Stinville, J.C.; Villechaise, P.; Renault, P.O.; Abrasonis, G.; Rivière, J.P.; Martinavičius, A.; Drouet, M. On lattice plane rotation and crystallographic structure of the expanded austenite in plasma nitrided AISI 316L steel. Surf. Coat. Technol. 2010, 204, 2551-2558. [CrossRef]

61. Lei, M.K. Phase transformations in plasma source ion nitrided austenitic stainless steel at low temperature. J. Mater. Sci. 1999, 34, 5975-5982. [CrossRef]

62. Yakubtsov, I.A.; Ariapour, A.; Perovic, D.D. Effect of nitrogen on stacking fault energy of f.c.c. iron-based alloys. Acta Mater. 1999, 47, 1271-1279. [CrossRef]

63. Borgioli, F.; Galvanetto, E.; Bacci, T. Low temperature nitriding of AISI 300 and 200 series austenitic stainless steels. Vacuum 2016, 127, 51-60. [CrossRef]

64. Manova, D.; Lutz, J.; Mändl, S. Sputtering effects during plasma immersion ion implantation of metals. Surf. Coat. Technol. 2010, 204, 2875-2880. [CrossRef]

65. Borgioli, F.; Fossati, A.; Galvanetto, E.; Bacci, T.; Pradelli, G. Glow discharge nitriding of AISI 316L austenitic stainless steel: Influence of treatment pressure. Surf. Coat. Technol. 2006, 200, 5505-5513. [CrossRef]

66. Ruset, C.; Ciuca, S.; Grigore, E. The influence of the sputtering process on the constitution of the compound layers obtained by plasma nitriding. Surf. Coat. Technol. 2003, 174-175, 1201-1205. [CrossRef]

67. Sundaraman, D.; Kuppusami, P.; Raghunathan, V.S. Some observations of the ion nitriding behaviour of a type 316 stainless steel. Surf. Technol. 1983, 18, 341-347. [CrossRef]

68. Roliński, E. Plasma-assisted nitriding and nitrocarburizing of steel and other ferrous alloys. In Thermochemical Surface Engineering of Steels: Improving Materials Performance; Mittemeijer, E.J., Somers, M.A.J., Eds.; Woodhead Publishing: Cambridge, UK, 2015; pp. 413-457. ISBN 9780857095923. [CrossRef]

69. Singh, G.P.; Alphonsa, J.; Barhai, P.K.; Rayjada, P.A.; Raole, P.M.; Mukherjee, S. Effect of surface roughness on the properties of the layer formed on AISI 304 stainless steel after plasma nitriding. Surf. Coat. Technol. 2006, 200, 5807-5811. [CrossRef]

70. Wenzel, R.N. Resistance of solid surfaces to wetting by water. Ind. Eng. Chem. 1936, 28, 988-994. [CrossRef]

71. Cassie, A.B.D.; Baxter, S. Wettability of porous surfaces. Trans. Faraday Soc. 1944, 40, 546-551. [CrossRef] 
72. Zhu, X.M.; Lei, M.K. Pitting corrosion resistance of high nitrogen f.c.c. phase in plasma source ion nitrided austenitic stainless steel. Surf. Coat. Technol. 2000, 131, 400-403. [CrossRef]

73. Flis-Kabulska, I.; Sun, Y.; Flis, J. Monitoring the near-surface $\mathrm{pH}$ to probe the role of nitrogen in corrosion behaviour of low-temperature plasma nitrided 316L stainless steel. Electrochim. Acta 2013, 104, 208-215. [CrossRef] 